\title{
How free access internet resources benefit biodiversity and conservation research: Trinidad and Tobago's endemic plants and their conservation status
}

\author{
VeERle Van Den Eynden, Michael P. OAtham and Winston Johnson
}

\begin{abstract}
Botanists have been urged to help assess the conservation status of all known plant species. For resourcepoor and biodiversity-rich countries such assessments are scarce because of a lack of, and access to, information. However, the wide range of biodiversity and geographical resources that are now freely available on the internet, together with local herbarium data, can provide sufficient information to assess the conservation status of plants. Such resources were used to review the vascular plant species endemic to Trinidad and Tobago and to assess their conservation status. Fifty-nine species were found to be endemic, much lower than previously stated. Using the IUCN Red List criteria 18 endemic species were assessed as Critically Endangered, 16 as Endangered, 15 as Vulnerable, three as Near Threatened, and three as Data Deficient (i.e. insufficient data are available to assess their conservation status). Although such rapid assessments cannot replace in depth research, they provide essential baseline information to target research and conservation priorities and identify specific conservation actions.
\end{abstract}

Keywords Database, endemic species, endemism, island, plant conservation, Trinidad and Tobago.

\section{Introduction}

Tn 2002 the Global Strategy for Plant Conservation called 1 for a preliminary assessment of the conservation status of all known plant species by 2010 as one of its 16 targets (Convention on Biological Diversity, 1993). To date the conservation status of $<5 \%$ of the world's plant species has been assessed (Krupnick \& Kress, 2006). Plant taxonomists and herbaria have been urged to assist by using distribution data from herbarium resources to assess threatened plant species (Callmander et al., 2005). Herbarium data in combination with a geographical information system (GIS) can be useful for assessments based on certain criteria, although

Veerle Van Den Eynden (Corresponding author) and Michael P. Oатнам Department of Life Sciences, University of the West Indies, St. Augustine, Trinidad, Trinidad and Tobago. E-mail veerle.eynden@sta. uwi.edu

Winston Johnson National Herbarium of Trinidad and Tobago, University of the West Indies, St. Augustine, Trinidad, Trinidad and Tobago.

Received 21 February 2007. Revision requested 8 June 2007.

Accepted 20 August 2007. one must be aware of the possible limitations (Willis et al., 2003).

Most European and North American countries have their flora and its conservation status well-documented through regularly updated Red Data lists (Strahm, 2003). For tropical countries, which are much richer in biodiversity but poorer in economic resources, such assessments remain scarce. Some exceptions are the recent Red Data lists of endemic plant species for Ecuador and Peru, completed through collaborations between local and international taxonomists (Valencia et al., 2000; León et al., 2006).

Access to and sharing of information, which are essential for plant conservation research (Gaikwad \& Chavan, 2006), are often lacking. Developing countries can benefit from free access and data sharing but are often unaware of the range of resources available. With advances in information technology and data sharing being high on the international research agenda (Arzberger et al., 2004; Edwards, 2004), the amount of freely accessible international biodiversity data that can be used to achieve plant conservation goals in developing countries is increasing.

The flora of Trinidad and Tobago, a 5,126 km Caribbean twin island nation, is estimated to include 2,500 vascular plant species (Kenny et al., 1997). Both islands lie on the South American Continental Shelf. Tobago was separated from the South American continent c. 13,000 years ago, and Trinidad possibly only 1,500 years ago (Van der Hammen, 1974; Rohr, 1991).

Although the country's flora is well documented, there is little information available on the conservation status of the vascular plants (Environmental Management Authority, 2001). The 2007 IUCN Red Data List includes only seven species from Trinidad and Tobago. Swietenia mahagoni is categorized as Endangered, Bactris setulosa and Solanum tobagense as Near Threatened, Ficus amazonica, Pradosia grisebachii and Pterocarpus santalinoides as Least Concern (this latter category indicates that the species have been assessed and found not to be currently in any danger of extinction), and Podocarpus trinitensis, which is endemic to Trinidad, as Data Deficient (IUCN, 2007).

Conservation of endemic species is deemed a priority for each country signatory to the Convention on Biological Diversity. The number of endemic plants in a country provides a good surrogate for the number of threatened 
plants of global importance (Pitman \& Jørgensen, 2002) but no accurate working list of endemic vascular plant species exists for Trinidad and Tobago. In the Flora of Trinidad and Tobago (Williams et al., 1928-1992) c. 160 plant species are described as endemic. This excludes plant families not incorporated in the Flora (Arecaceae, Podocarpaceae and Poaceae). Adams \& Baksh (1981) stated that 215 plant species are endemic, without providing a species list. A list compiled by consultants for an FAO report mentions 85 endemic plant species (MALMR, 1995) but contains inaccuracies. The 2001-2002 State of the Environment Report (Agard \& Gowrie, 2003) estimates that 91 plant species are endemic, without providing species names.

Here we review which vascular plant species are endemic to Trinidad and Tobago and assess their conservation status. We do this in a way that is feasible and accessible for any resource-poor nation by using free access internet resources and local herbarium data. Based on this we describe specific actions for conservation of the resulting list of endemic species.

\section{Methods}

A base list of potentially endemic plant species was drawn up from secondary sources (Williams et al., 1928-1992; Sleumer, 1980; Panter, 1981; MALMR, 1995; Wasshausen, 1995; Wasshausen \& McClellan, 1995). Geographical distribution, existing herbarium specimens, collection dates and sites, taxonomic synonymy and possible name changes of these species were reviewed using free access internet electronic databases (Boggan et al., 1997; Royal Botanic Gardens Kew, 2002; International Legume Database and Information Service, 2005; Skog \& Boggan, 2005-2006; The Board of Trustees of the Royal Botanic Gardens Kew, 2006a, b; Missouri Botanical Garden, 2006; The New York Botanical Garden, 2006). The same sources were also consulted for potential additional endemic species. From this review a species on the base list was either confirmed as not endemic to Trinidad and Tobago or marked for further verification.

For the latter group, additional collection localities for each species were obtained from herbarium specimens held in the Trinidad and Tobago National Herbarium (TRIN). Taxonomists were located using the online search engine Google (2006) and were asked by e-mail for advice and information on species distribution, synonymy and endemism. Of 30 people contacted, 26 provided information.

The global conservation status of each species on our final list of endemic plant species was assessed using the IUCN Red List criteria v. 3.1 (IUCN, 2001). Assessments were based primarily on geographic range in the form of extent of occurrence (EOO) or area of occupancy (AOO), the number of collection localities for a species (available from herbarium specimens), and observed, inferred or projected decline in $\mathrm{EOO}$ or $\mathrm{AOO}$ or habitat quality. $\mathrm{EOO}$ and $\mathrm{AOO}$ were calculated following the methods of Willis et al. (2003), using the GIS ArcView v. 3.2 (ESRI, Redlands, USA) and a freely available GIS base map (Bletter et al., 2006) with coordinates generated from herbarium specimen collection localities. The grid cell size used for AOO calculations was based on the Kew algorithm (cell side $=10 \%$ of the distance between furthest collection localities; Willis et al., 2003). Geographical co-ordinates of collection localities were generated using 1:25,000 topographic maps and GIS layers derived from them. A vegetation formation GIS map layer (World Conservation Monitoring Centre, 1996; only available for Trinidad), a GIS gazetteer layer of place names for Trinidad and Tobago (United States Board on Geographic Names, 2006) and a land use GIS layer (Ramlal, unpubl. data) were also used. Uncertainty was inherent in the generation of co-ordinates for localities given on linear features (roads or rivers) but this uncertainty did not affect the $\mathrm{AOO}$ or EOO so as to change the conservation status of a species (assessed by calculating minimum and maximum values for $\mathrm{AOO}$ and $\mathrm{EOO}$ ).

Inferred or projected decline of a species was based on existing land use patterns, occurrence in or absence from protected areas and forest reserves, the management and security of these areas (based on our personal knowledge), and inferred climate change effects for species restricted to high altitude habitats. Freely available GIS layers of protected areas (World Database on Protected Areas, 2005) and land use (European Commission Joint Research Centre, 2002) were also used.

This review and assessment required an approximate input of 105 person hours: 6o hours species review and database consultation, 10 hours herbarium consultation, 20 hours geo-referencing, 10 hours GIS analyses, and 5 hours of conservation assessments.

\section{Results}

Starting from a base list of 222 potentially endemic plant species, 158 (71\%) were found not to be endemic and thus eliminated after consulting internet resources containing detailed taxonomic and distributional information. Through soliciting expert taxonomic opinion, another 16 species were found not to be endemic, 23 were positively confirmed to be endemic and 3 species were added to the base list. Further in depth revision of the internet sources confirmed another 25 species as endemic. For eight species no positive confirmation of endemism or non-endemism could be obtained. Because they were considered to be endemic at the time of publishing of the relevant Flora of Trinidad and Tobago fascicle, they remain included in the list of endemic species.

In total we thus found 59 vascular plant species to be endemic to Trinidad and Tobago (Table 1): six occur on 
TABLE 1 The 59 endemic plants of Trinidad and Tobago, with the number of distinct locations in which they are or were known, year last collected (if before 1958), Red List categorization and criteria, occurrence in protected areas, and suggested actions required for their conservation.

\begin{tabular}{|c|c|c|c|c|c|c|c|c|}
\hline Species & Family & Trinidad & Tobago & $\begin{array}{l}\text { No. of } \\
\text { distinct } \\
\text { locations }{ }^{1}\end{array}$ & $\begin{array}{l}\text { Year last } \\
\text { collected }\end{array}$ & $\begin{array}{l}\text { Red List } \\
\text { category \& } \\
\text { criteria }^{2}\end{array}$ & $\begin{array}{l}\text { Occurrence } \\
\text { in protected } \\
\text { areas }^{3}\end{array}$ & $\begin{array}{l}\text { Conservation } \\
\text { actions }\end{array}$ \\
\hline \multicolumn{9}{|l|}{ Known from recent collections } \\
\hline Justicia flaviflora (Turrill) Wassh. & Acanthaceae & $\mathrm{X}$ & & 2 & & CR B1ab(iii) & & $\mathrm{H} / \mathrm{E}$ \\
\hline Odontonema brevipes Urb. & Acanthaceae & & $\mathrm{X}$ & 4 & & VU D2 & MRFR & \\
\hline Duguetia tobagensis (Urb.) R. E. Fr. & Annonaceae & & $\mathrm{X}$ & 4 & & VU D2 & MRFR & \\
\hline Philodendron simmondsii Mayo & Araceae & $\mathrm{X}$ & & 4 & & EN B1ab(iii)+2ab(iii) & LSFR, MFR, SFR & $\mathrm{E} / \mathrm{T}$ \\
\hline Aristolochia boosii Panter & Aristolochiaceae & $\mathrm{X}$ & & 3 & & EN B1ab(iii)+2ab(iii) & CFR, EFR & $\mathrm{E} / \mathrm{T}$ \\
\hline Cynanchum freemani (N.E.Br.) Woodson & Asclepiadaceae & $\mathrm{X}$ & & 3 & & EN B1ab(iii)+2ab(iii) & & $\mathrm{P} / \mathrm{E} / \mathrm{T}$ \\
\hline Begonia mariannensis Wassh. \& McClellan & Begoniaceae & $\mathrm{X}$ & & 2 & & VU D2 & & $\mathrm{E} / \mathrm{T}$ \\
\hline Werauhia broadwayi (L.B.Smith) J.R.Grant & Bromeliaceae & $\mathrm{X}$ & $\mathrm{X}$ & 3 & & NT & MRFR, NRFRB & \\
\hline Marthella trinitatis (Johow) Urb. & Burmanniaceae & $\mathrm{X}$ & & 1 & & CR B1ab(iii) & NRFRB & $\mathrm{H} / \mathrm{E}$ \\
\hline Maytenus monticola Sandwith & Celastraceae & $\mathrm{X}$ & $\mathrm{X}$ & 6 & & $\mathrm{LC}$ & MFREE, MRFR & \\
\hline Clusia aripoensis Britton & Clusiaceae & $\mathrm{X}$ & & 6 & & EN B1ab(iii)+2ab(iii) & DFR, MFREE, NRFRA, NRFRB & $\mathrm{H}$ \\
\hline Clusia intertexta Britton & Clusiaceae & $\mathrm{X}$ & & 1 & & CR B1ab(iii) & & $\mathrm{H} / \mathrm{E}$ \\
\hline Clusia tocuchensis Britton & Clusiaceae & $\mathrm{X}$ & & 4 & & EN B1ab(iii)+2ab(iii) & MFREE, NRFRB & $\mathrm{H}$ \\
\hline Sicana trinitensis Cheesman & Cucurbitaceae & $\mathrm{X}$ & & 2 & & EN B1ab(iii)+2ab(iii) & & $\mathrm{E} / \mathrm{T}$ \\
\hline Rhynchospora ierensis C.Adams & Cyperaceae & $\mathrm{X}$ & & 2 & & EN B1ab(iii)+2ab(iii) & EFR & $\mathrm{E} / \mathrm{T}$ \\
\hline Scleria orchardii C.Adams & Cyperaceae & $\mathrm{X}$ & & 2 & & CR B1ab(iii)+2ab(iii) & NRFRA & $\mathrm{H} / \mathrm{E}$ \\
\hline Acalypha grisebachiana (Kuntze) Pax \& Hoffm. & Euphorbiaceae & $\mathrm{X}$ & & 17 & & LC & CFR, MEFR, NRFRB, VMFR & \\
\hline Phyllanthus acacioides Urb. & Euphorbiaceae & & $\mathrm{X}$ & 1 & & VU D2 & MRFR & \\
\hline Besleria seitzii Krug \& Urb. & Gesneriaceae & & $\mathrm{X}$ & 5 & & VU D2 & MRFR & \\
\hline Ocotea trinidadensis Kosterm. & Lauraceae & $\mathrm{X}$ & & 4 & & VU B1ab(iii)+2ab(iii) & DFR, MFREE, NRFRA & \\
\hline Macrolobium trinitense Urb. & Leguminosae & $\mathrm{X}$ & & 4 & & EN B1ab(iii)+2ab(iii) & MFREE, NRFRB & \\
\hline Phoradendron hartii Krug \& Urb. & Loranthaceae & $\mathrm{X}$ & & 3 & & EN B1ab(iii)+2ab(iii) & & $\mathrm{E} / \mathrm{D} / \mathrm{T}$ \\
\hline Marcgravia elegans Krug \& Urb. & Marcgraviaceae & $\mathrm{X}$ & & 2 & & EN B1ab(iii)+2ab(iii) & NRFRB & $\mathrm{H} / \mathrm{E}$ \\
\hline Cybianthus cruegeri Mez & Myrsinaceae & $\mathrm{X}$ & & 2 & & EN B1ab(iii)+2ab(iii) & & $\mathrm{H} / \mathrm{E}$ \\
\hline Cybianthus pittieri Agostini & Myrsinaceae & & $\mathrm{X}$ & 1 & & VU D2 & MRFR & \\
\hline Eugenia cruegeri Krug \& Urb. ex Urb. & Myrtaceae & $\mathrm{X}$ & $\mathrm{X}$ & 6 & & LC & DFR, CRFR, MFREE, MRFR & \\
\hline Cochleanthes trinitatis (Ames) R.E. Schult. \& Garay & Orchidaceae & $\mathrm{X}$ & & 2 & & EN B2ab(iii) & & $\mathrm{E} / \mathrm{P}$ \\
\hline Epidendrum hombersleyi Summerh. & Orchidaceae & $\mathrm{X}$ & & 6 & & VU B1ab(iii)+2ab(iii) & AFR, CRFR, LSFR & \\
\hline Microchilus schultesianus (Garay) Ormerod & Orchidaceae & $\mathrm{X}$ & & 3 & & EN B1ab(iii)+2ab(iii) & NRFRA, NRFRB & $\mathrm{H} / \mathrm{E}$ \\
\hline Podocarpus trinitensis Buchh. \& Gray & Podocarpaceae & $\mathrm{X}$ & & 13 & & LC & CRFR, MFRWE, NRFRB & \\
\hline Polygala exserta Blake & Polygalaceae & $\mathrm{X}$ & & 4 & & CR B1ab(iii)+2ab(iii) & LSFR & $\mathrm{A} / \mathrm{L} / \mathrm{E}$ \\
\hline Securidaca lophosoma (Blake) Cheesman & Polygalaceae & $\mathrm{X}$ & & 2 & & VU D2 & & \\
\hline Coccoloba nigrescens Lindau & Polygonaceae & $\mathrm{X}$ & & 2 & & VU D2 & & $\mathrm{D} / \mathrm{E}$ \\
\hline Rondeletia hispidula (Griseb.) K. Schum. & Rubiaceae & $\mathrm{X}$ & & 2 & & EN B1ab(iii)+2ab(iii) & NRFRB & $\mathrm{H} / \mathrm{E}$ \\
\hline Pilea tobagensis Urb. & Urticaceae & & $\mathrm{X}$ & 2 & & VU D2 & LTWS, MRFR & \\
\hline Aegiphila obovata Andr. & Verbenaceae & $\mathrm{X}$ & $\mathrm{X}$ & 4 & & NT & MRFR & \\
\hline Xyris grisebachii Malme & Xyridaceae & $\mathrm{X}$ & & 4 & & CR B1ab(iii)+2ab(iii) & LSFR & $\mathrm{A} / \mathrm{L} / \mathrm{E}$ \\
\hline
\end{tabular}


Known from single type collections pre-1958 or not collected since 1958

Dicliptera aripoensis (Britton) Leonard

Acanthaceae

Justicia tobagensis (Urb.) Wassh.

Gonolobus tobagensis Urb.

Mikania broadwayi B.L.Rob.

Begonia eciliata Schulz.

Aechmea downsiana Pittendrigh

Maytenus reflexa Urb.

Dicranopygium insulare (Gleas.) Harl.

Rhynchospora aripoensis Britton

Rhynchospora ebracteata (Standl.) H.Pfeiff

Eriocaulon caesium Griseb.

Croton aripoensis Philcox

Phyllanthus mimicus Webster

Xylosma sanctae-annae Sleumer

Besleria strigillosa Urb.

Epidendrum fusiforme (Lindl.) Rchb.

Epidendrum lanceolatum Bradford ex Griseb.

Maxillaria broadwayi (Cogn.) R.E. Schult.

Neurolepis virgata (Griseb.) Pilg.

Roupala tobagensis Sleumer

Psychotria rufidula Standl.

Rondeletia rohrii R.O.Williams \& Cheesman

$\begin{array}{lll}\text { Acanthaceae } & \mathrm{X} & \\ \text { Ácanthaceae } & & \mathrm{X} \\ \text { Asclepiadaceae } & \mathrm{X} & \mathrm{X} \\ \text { Asteraceae } & \mathrm{X} & \\ \begin{array}{l}\text { Begoniaceae } \\ \text { Bromeliaceae }\end{array} & \mathrm{X} & \\ \text { Celastraceae } & \mathrm{X} & \\ \begin{array}{l}\text { Cyclanthaceae } \\ \text { Cyperaceae }\end{array} & \mathrm{X} & \mathrm{X} \\ \begin{array}{l}\text { Cyperaceae } \\ \text { Eriocaulaceae }\end{array} & \mathrm{X} & \mathrm{X} \\ \begin{array}{l}\text { Euphorbiaceae } \\ \text { Euphorbiaceae }\end{array} & \mathrm{X} & \\ \begin{array}{l}\text { Flacourtiaceae } \\ \text { Gesneriaceae }\end{array} & \mathrm{X} & \mathrm{X} \\ \begin{array}{l}\text { Orchidaceae } \\ \text { Orchidaceae } \\ \text { Orchidaceae }\end{array} & \mathrm{X} & \\ \text { Poaceae } & \mathrm{X} & \\ \text { Proteaceae } & \mathrm{X} & \\ \text { Rubiaceae } & \mathrm{X} & \mathrm{X} \\ \text { Rubiaceae } & & \end{array}$

$\begin{array}{lll}1934 & \text { CR B1ab(iii) } & \\ 1954 & \text { VU D2 } & \text { MRFR } \\ 1938 & \text { NT } & \text { MRFR } \\ 1922 & \text { CR B1ab(iii) } & \\ \text { Pre-1911 } & \text { CR B1ab(iii) } & \\ 1958 & \text { CR B1ab(iii) } & \\ 1904 & \text { DD } & \\ 1937 & \text { VU B1ab(iii)+2ab(iii) } & \\ 1921 & \text { CR B1ab(iii) } & \text { LSFR } \\ 1937 & \text { VU D2 } & \\ 1867 & \text { CR B1ab(iii) } & \\ 1934 & \text { CR B1ab(iii) } & \\ 1909 & \text { CR B1ab(iii) } & \\ 1927 & \text { EN B1ab(iii)+2ab(iii) } & \\ 1901 & \text { DD } & \\ ? & \text { VU B1ab(iii)+2abiii } & \text { AFR } \\ ? & \text { CR B1ab(iii) } & \\ ? & \text { CR B1ab(iii) } & \\ 1948 & \text { CR B1ab(iii) } & \text { NRFRB } \\ 1910 & \text { CR B1ab(iii) } & \\ 1929 & \text { EN B1ab(iii) } & \text { VMFR } \\ 1786-91 & \text { DD } & \end{array}$

$\mathrm{R} / \mathrm{H} / \mathrm{E}$

$\mathrm{R}$

$\mathrm{R}$

$\mathrm{R} / \mathrm{H} / \mathrm{E}$

$\mathrm{R} / \mathrm{E} / \mathrm{T}$

$\mathrm{F}$

$\mathrm{R}$

$\mathrm{A} / \mathrm{L} / \mathrm{E}$

$\mathrm{A} / \mathrm{L} / \mathrm{E}$

$\mathrm{R} / \mathrm{H} / \mathrm{E}$

$\mathrm{R} / \mathrm{E} / \mathrm{T}$

$\mathrm{D} / \mathrm{E}$

$\mathrm{R}$

$\mathrm{R} / \mathrm{E} / \mathrm{T}$

$\mathrm{R} / \mathrm{H} / \mathrm{E}$

$\mathrm{H} / \mathrm{E}$

$\mathrm{R} / \mathrm{E} / \mathrm{T}$

$\mathrm{R} / \mathrm{E} / \mathrm{T}$

$\mathrm{F}$

${ }^{1}$ Based on herbarium records

${ }^{2}$ CR, Critically Endangered; EN, Endangered; VU, Vulnerable; NT, Near Threatened; DD, Data Deficient; LC, Least Concern (LC indicates the species has been assessed and found not to be in danger of extinction). See IUCN (2001) for details of criteria.

${ }^{3}$ AFR, Arena Forest Reserve; CFR, Cedros Forest Reserve; CRFR, Central Range Forest Reserve; DFR, St David Forest Reserve (includes part of Matura Environmentally Sensitive Area); EFR, Erin Forest Reserve; LSFR, Long Stretch Forest Reserve (includes Aripo Savannah Scientific Reserve); LTWS, Little Tobago Wildlife Sanctuary; MFR, Melajo Forest Reserve; MFREE, Matura Forest Reserve Eastern Extension (includes part of Matura Environmentally Sensitive Area); MFRWE, Matura Forest Reserve Western Extension; MEFR, Morne l'Enfer Forest Reserve; MRFR, Main Ridge Forest Reserve; NRFRA, Northern Range Forest Reserve Section A; NRFRB, Northern Range Forest Reserve Section B; SFR, Siparia Forest Reserve; VMFR, Victoria-Mayaro Forest Reserve (see Fig. 1 for locations)

${ }^{4} \mathrm{~A}$, ensure effective protection for Aripo Savannah Scientific Reserve (through government or communities); D, create dry forest protected area; E, ex situ conservation; F, find locality of Data Deficient species; H, create Heights of Aripo protected area; L, survey for presence in Aripo Savannah Scientific Reserve; P, create site-specific protected area; R, relocate species at original collection site; T, translocate to suitable protected area. 
both islands; 12 are endemic to Tobago only and 39 to Trinidad. For two species, known only from a single collection, no locality information was recorded on the specimen sheets. Twenty-two species are either known only from their respective type collections that date from before 1958, or have not been collected since 1958 (Table 1). Only extensive field research will determine whether these species are still extant or whether they are simply rare. Various species in the list have never been reviewed by taxonomists at a regional level. They could be synonymous to plant species found elsewhere but until such revisions prove otherwise, these species should continue to be considered endemic. The current number of known endemic plant species is thus significantly lower than previously stated numbers, and could be lower still, possibly as low as 40 species.

Plant endemism on Trinidad and Tobago was found to be concentrated in three main localities (Fig. 1): ridge tops of the Northern Range in Trinidad (18 species), edaphic savannahs of northern Trinidad (6 species), and the Main Ridge in Tobago (11 species). Of the 59 endemic plant species, 18 were found to be Critically Endangered, 16 Endangered, 15 Vulnerable, three Near Threatened, and four were assessed as species of Least Concern (Tables 1-2).
Three species were categorized as Data Deficient because they could not be assessed from currently available data or had vague collection locality data.

\section{Discussion}

Research institutes that use information technology to catalogue and distribute information online promote the advancement of knowledge at a global scale. Using such free-access online resources, and advice offered freely by taxonomy experts, a review of the endemic vascular plant species of Trinidad and Tobago and an assessment of their conservation status was carried out in a relatively short time and without significant cost. This in turn has been made freely available online (Van den Eynden, 2006). Such rapid evaluation of conservation status cannot replace the need for in depth field-based monitoring and assessment but it provides valuable baseline information for the identification and targeting of specific conservation and research needs. The methods used can be applied by most countries for initial assessments of plant extinction risks. Lack of resources or research data is no longer an argument not to do so.

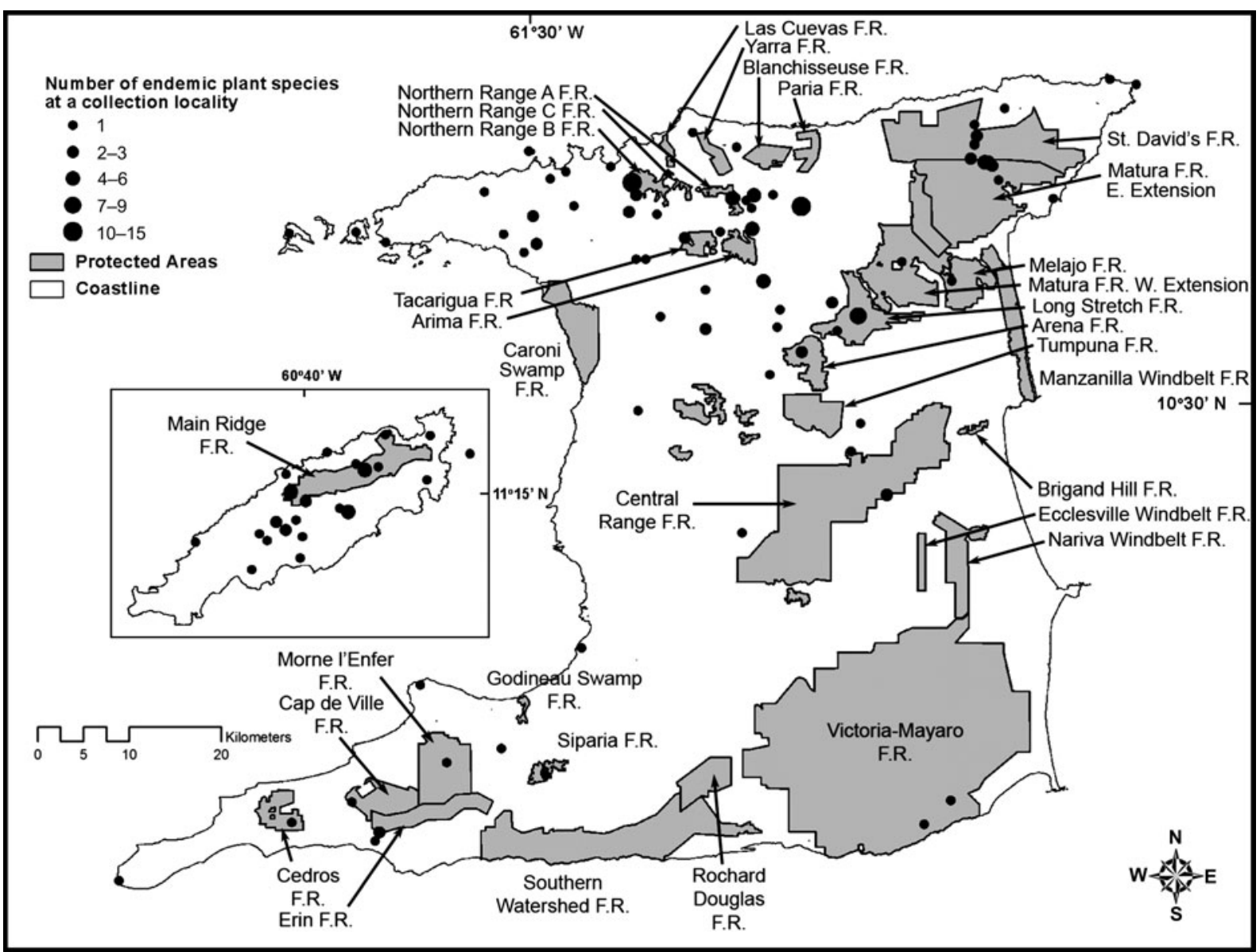

FIg. 1 Geographical distribution of endemic plant species (see Table 1) in Trinidad (main map) and Tobago (inset), and the locations of protected areas. F.R., Forest Reserve. 
TABLE 2 Conservation assessment of endemic vascular plant species of Trinidad and Tobago, with total number of species in each Red List category (IUCN, 2001) and number of species not known to occur in existing protected areas.

\begin{tabular}{lll}
\hline Red List category & $\begin{array}{l}\text { No. of } \\
\text { species }\end{array}$ & $\begin{array}{l}\text { No. of species } \\
\text { not found in } \\
\text { protected areas }\end{array}$ \\
\hline Critically Endangered & 18 & 12 \\
Endangered & 16 & 6 \\
Vulnerable & 15 & 5 \\
Near Threatened & 3 & 0 \\
Least Concern & 4 & 0 \\
Data Deficient & 3 & - \\
Total & 59 & 23 \\
\hline
\end{tabular}

Relying solely on herbarium data may under- or overestimate the conservation risk if collection data do not truly represent species distribution. Herbarium data used in this assessment span over a century, and locality data from older collections may no longer represent a species' range. However, we balanced this uncertainty with our field knowledge of localities. Herbarium collections in the country tend to be biased towards areas accessible by road, forest areas and protected areas, and relatively fewer collections exist for Tobago. There may also be relative under-collection of small herbaceous species compared to tree and shrub species. Both factors may cause overestimation of extinction risk. Using the range criterion almost exclusively may not take account of species that are secure and with a naturally small range or species in the process of going extinct because their habitat has been destroyed or fragmented beyond a critical level.

This review shows that in Trinidad and Tobago $<3 \%$ of all vascular plant species are endemic. Many species previously perceived as endemic were found not to be so. Increased plant collecting in neighbouring continental areas and taxonomic reviews at a regional level show many species to be synonymous to those on the South American mainland. The length of time Trinidad and Tobago have been separated from the mainland is too short for island endemism to have developed to the same extent as on an oceanic island such as Jamaica (MacArthur, 1972). The true number of endemics will probably be found to be lower still when further regional taxonomic reviews are carried out.

Using current IUCN criteria $58 \%$ of the 59 endemic species were categorized as Endangered or Critically Endangered. These must be considered as priority species for conservation, and further research of their population status is urgently needed. The 22 species not collected for several decades or known only from type collections are priority species for assessment of distribution and population status, and urgently need to be relocated in their respective locations. In addition, all species should be surveyed for presence in protected areas and should be inventoried in any environmental impact assessments.
This review also provides information for policy makers in terms of protected area management. The gazetted protected area network of Trinidad and Tobago encompasses $56 \%$ of all endemic vascular plant species, with 23 species not represented in the network (Table 2, Fig. 1) and $60 \%$ of Critically Endangered and 38\% of Endangered species not safeguarded in protected areas. Six Critically Endangered and six Endangered species would be protected by a new protected area containing the Heights of Aripo on Trinidad and two Endangered species require a protected area of dry deciduous forest. In situ conservation may not be appropriate for high altitude ridge top species under threat from global climate change, and ex situ conservation should be pursued as a precaution. Ten endemic species not present in protected areas are likely to occur in them as they are found in close proximity to or in habitats represented in protected areas. However, many areas are only protected on paper, especially protected areas near population centres. Most Forest Reserves are used for selective timber extraction and some, such as the Central Range Forest Reserve, have been largely converted to exotic timber plantations.

The protected areas critical for the conservation of endemic plant species are the Main Ridge Forest Reserve, the Aripo Savannah Scientific Reserve, and the Northern Range Forest Reserve (parts A, B and C). The Main Ridge Forest Reserve in Tobago is considered to be relatively secure from human and environmental change pressures at present, although its small size makes it vulnerable to fire or hurricane damage. The Aripo Savannah Scientific Reserve (part of Long Stretch Reserve) is the only protected natural savannah habitat in Trinidad. It is, however, not adequately protected and human development continues to encroach on the area. Future plans to create a major population centre on the boundaries of the reserve increase the threat of degradation and conversion to residential land use. The fact that it harbours six endemic plants restricted to this habitat indicates the urgent need to protect this area effectively. In the Northern Range Forest Reserve the potential impacts of climate change on ridge top vegetation communities is a cause of concern for endemics restricted to this habitat. This reserve is open to extractive use of timber, game animals, non-timber forest products and, potentially, limestone quarrying. The Northern Range Forest Reserve and the recently declared Matura National Park Environmentally Sensitive Area (part of Matura Forest Reserve Eastern Extension and St David Forest Reserve) are the only protected areas for the Northern Range's ridges, containing 15 endemic species. A recent vegetation survey in Matura National Park recorded only seven of the Northern Range endemic species within the Park's boundaries (Van den Eynden et al., 2007). The Heights of Aripo, where 12 endemic species were collected in the Northern Range, is currently not protected, indicating the urgent need to do so. 
All conservation assessments with detailed supporting evidence are being submitted to IUCN for inclusion in the IUCN Red List. Since this work was completed the Aripo Savannah Scientific Reserve has been declared an Environmentally Sensitive Area, the highest level of protected area status currently existing in the country. Funds have been provided by the government to investigate the status of endemic plants found in the reserve. An extensive botanical survey to monitor habitat and species distribution by Oxford University, UK, and the National Herbarium of Trinidad and Tobago, funded under the UK Darwin Initiative, will be completed in 2008 and should provide details of more localities of endemic plant species to update the list presented here.

\section{Acknowledgements}

The authors thank the following (with herbaria abbreviations) for providing valuable information: Frank Almeda, CAS (Melastomataceae), Tom Croat, MO (Araceae), Garrett Crow, NHA (Lentibulariaceae), Tom Daniel, CAS (Acanthaceae), Stefan Dressler, FR (Marcgraviaceae), Barry Hammel, MO (Clusiaceae), Kehan Harman, K (Poaceae), Walter Holmes, BAYLU (Asteraceae), Sandra Knapp, BM (Solanaceae), Robert Kral, VDB (Xyridaceae), Alexander Krings, NCSC (Asclepiadaceae), Job Kuijt, UVIC (Loranthaceae), Gwilym Lewis, K (Leguminosae), Raphael Lira, UNAM (Cucurbitaceae), Eve Lucas, K (Myrtaceae), Harry Luther, SEL (Bromeliaceae), Paul Maas, U (Annonaceae, Burmanniaceae), Robert Mill, E (Podocarpaceae), Francisco Morales, INB (Apocynaceae), John Pipoly, FTG (Myrsinaceae), Ghillean Prance (Proteaceae), Elmar Robbrecht, BR (Rubiaceae), Mark Simmons, CS (Celastraceae), Laurence Skog, US (Gesneriaceae), Charlotte Taylor, MO (Rubiaceae), Thomas Wayt, NY (Cyperaceae), and the Trinidad and Tobago Orchid Society. We thank the National Herbarium of Trinidad and Tobago for access to their plant collection and the many, often anonymous, people that have produced the extensive free online resources consulted in this study.

\section{References}

AdAms, C.D. \& BAKSH, Y.S. (1981) What is an endangered plant? Living World, 1981-1982, 9-14.

Agard, J.B.R. \& Gowrie, M. (2003) Environmental Vulnerability Index (EVI): Provisional Indices and Profiles for Trinidad and Tobago. State of the Environment Report 2001 \& 2002. Environmental Management Authority, Port of Spain, Trinidad and Tobago.

Arzberger, P., Schroeder, P., Beaulieu, A., Bowker, G., Casey, K., LaAksonen, L. et al. (2004) Promoting access to public research data for scientific, economic, and social development. Data Science Journal, 3, 135-152.

Bletter, N., Janovec, J., Brosi, B. \& Daly, D.C. (2004) A Digital Base Map for Studying the Neotropical Flora. The New York Botanical Garden, New York, USA. Http://www.nybg.org/
bsci/acre/wwwl/AmericasBaseMap.html [accessed 14 November 2006].

Boggan, J.K., Funk, V.A., Kelloff, C.L. \& Hoff, M. (1997) Checklist of the Plants of the Guianas (Guyana, Surinam, French Guiana). Smithsonian Institution, Washington, DC, USA. Http:// www.mnh.si.edu/biodiversity/bdg/checklst.html [accessed 16 November 2006].

Callmander, M., Schatz, G. \& Lowry, P. (2005) IUCN Red List assessment and the Global Strategy for Plant Conservation: taxonomists must act now. Taxon, 54, 1047-1050.

Convention on Biological Diversity (1993) Http://www.cbd.int/ [accessed 20 February 2008].

EdWARDS, J.L. (2004) Research and societal benefits of the Global Biodiversity Information Facility. BioScience, 54, 486-487.

Environmental Management Authority (2001) Biodiversity Strategy and Action Plan for Trinidad and Tobago. Environmental Management Authority, Port of Spain, Trinidad and Tobago.

European Commission Joint Research Centre (2002) GLC 200o: Global Land Cover Mapping for the Year 200o. European Commission Joint Research Centre, Institute for Environment and Sustainability, Ispra, Italy. Http://www-gvm.jrc.it/glc20oo/ [accessed 20 February 2008].

Gaikwad, J. \& Chavan, V. (2006) Open access and biodiversity conservation: challenges and potentials for the developing world. Data Science Journal, 5, 1-17.

Google (2006) Http://www.google.com [accessed 1 May 2006]. International Legume Database and Information Service (2005) Http://www.ildis.org/LegumeWeb [accessed 16 November 2006].

IUCN (2001) 2001 Categories and Criteria (version 3.1). IUCN, Gland, Switzerland [http://www.redlist.org/info/categories_criteria2001. html, accessed 16 November 2006].

IUCN (2007) 2007 IUCN Red List of Threatened Species. IUCN, Gland, Switzerland. Http://www.iucnredlist.org/ [accessed 20 February 2008].

Kenny, J., Comeau, P. \& Katwaru, L.A. (1997) Trinidad \& Tobago Biological Diversity Survey. Extensive Extracts from a Survey of Biological Diversity, Trinidad and Tobago. Environmental Management Authority, Port of Spain, Trinidad \& Tobago.

Krupnick, G. \& Kress, J. (2006) Achieving Target 2 of the Global Strategy for Plant Conservation. Plant Talk, 43, 46-47.

León, B., Roque, J., Ulloa Ulloa, C., Pitman, N., Jørgensen, P.M. \& Cano, A. (eds) (2006) El libro rojo de las plantas endémicas del Perú. Revista peruana de biología, 13, 1-965.

MacArthur, R.H. (1972) Geographical Ecology. Harper \& Row, New York, USA.

MALMR (1995) Trinidad and Tobago: Country Report to the FAO International Technical Conference on Plant Genetic Resources. Ministry of Agriculture, Land and Marine Resources, Port of Spain, Trinidad and Tobago.

Missouri Botanical Garden (2006) W3 Tropicos VAST Nomenclature Database. Http://mobot.mobot.org/W3T/Search/vast.html [accessed 16 November 2006].

Panter, J.A. (1981) Notes on Aristolochia from Trinidad and the description of A. boosii. Kew Bulletin, 36, 231-233.

Pitman, N. \& Jørgensen, P. (2002) Estimating the size of the world's threatened flora. Science, 298, 989-989.

Rohr, G.M. (1991) Paleogeographic maps, Maturín Basin of E Venezuela and Trinidad. In Transactions of the Second Geological Conference of the Geological Society of Trinidad \& Tobago (ed. K.A. Gillezeau), pp. 88-105. The Geological Society of Trinidad and Tobago, Port of Spain, Trinidad and Tobago.

Royal Botanic Gardens Kew (2002) Electronic Plant Information Centre. Http://www.kew.org/epic/ [accessed 16 November 2006]. 
SKOG, L.E. \& BOGGAN, J.K. (2005-2006) World Checklist of Gesneriaceae. Smithsonian Institution, Washington, DC, USA.

Sleumer, H.O. (1980) Flacourtiaceae. Flora Neotropica Monograph, 22, $1-499$.

S Trahm, W. (2003) Global Strategy for Plant Conservation Draft Stakeholder Consultation on Target 2. IUCN, Gland, Switzerland.

The Board of Trustees of the Royal Botanic Gardens Kew (2006a) World Checklist of Monocotyledons. Http://www.kew.org/wcsp/ monocots/ [accessed 20 September 2006].

The Board of Trustees of the Royal Botanic Gardens Kew (2006b) World Checklist of Selected Plant Families. Http://www.kew.org/ wcsp/ [accessed 16 November 2006].

The New York Botanical Garden (2006) Virtual Herbarium. Http://sciweb.nybg.org/Science2/vii2.asp [accessed 16 November 2006].

United States Board on Geographic Names (2006) Trinidad and Tobago Country File. Http://earth-info.nga.mil/gns/html/cntry_ files.html [accessed 23 October 2006].

Valencia, R., Pitman, N., León-Yánez, S. \& Jørgensen, P.M. (2000) Libro rojo de las plantas endémicas del Ecuador. Herbario QCA, Pontificia Universidad Católica del Ecuador, Quito, Ecuador.

Van Den Eynden, V. (2006) Review of Endemic Plants of Trinidad and Tobago. Http://www.sta.uwi.edu/fsa/maturanp/ [accessed 2 August 2007].

Van Den Eynden, V., Oatham, M., Alexander, B., Naranjit, A., Quashie, J., Koonhow, B. et al. (2007) Matura National Park ESA Participatory Biological Baseline Survey. Unpublished Report. The University of the West Indies, St. Augustine, Trinidad.
Van der Hammen, T. (1974) The Pleistocene changes of vegetation and climate in tropical South America. Journal of Biogeography, 1 , $3-26$.

Wasshausen, D. (1995) A new species, new combinations, and a new name in Acanthaceae from northern South America. Brittonia, 47, 422-425.

Wasshausen, D. \& MCClellan, T. (1995) Begonia mariannensis (Begoniaceae), a new species from Trinidad, West Indies. Brittonia, 47, 21-23.

Williams, R.O., Cheesman, E.E. \& Philcox, D. (1928-1992) Flora of Trinidad and Tobago, Volumes 1-3. Government Printer, Port of Spain, Trinidad and Tobago.

Willis, F., Moat, J. \& Paton, A. (2003) Defining a role for herbarium data in Red List assessments: a case study of Plectranthus from eastern and southern tropical Africa. Biodiversity and Conservation, 12, 1537-1552.

World Conservation Monitoring Centre (1996) Forest Cover of Trinidad. Http://gislab.cifor.cgiar.org/fsic/doSearch.do?q= trinidad [accessed 4 June 2006].

World Database on Protected Areas (2005) Http://sea.unepwcmc.org/wdbpa [accessed 16 November 2006].

\section{Biographical sketches}

Veerle Van den Eynden specializes in how local people use and manage plants and the environment. She has carried out research on plant-people interactions in Africa and South America since 1991. Michael OAтнам's research interests include plant conservation, biogeography and management of tropical forests. WINSTON JOHNSON has worked at the National Herbarium of Trinidad and Tobago since 1981 and is an authority on the flora of Trinidad and Tobago. 